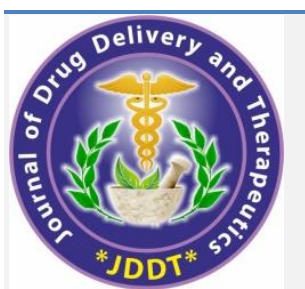

Open Access Full Text Article

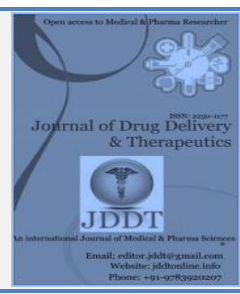

Review Article

\title{
Mechanisms of Action of Flavonoids in the Management of Diabetes mellitus
}

\author{
Namrata Jain ${ }^{1}$, S. Chandra Mohan ${ }^{1,2 *}$, S. Sumathi ${ }^{3}$ \\ ${ }^{1}$ Department of Chemistry, Sarvepalli Radhakrishnan University, NH-12, Hoshangabad Road, Jatkhedi, Bhopal- 462026, Madhya Pradesh, India. \\ ${ }^{2}$ Division of Phytochemistry, Shanmuga Centre for Medicinal Plants Research, Thanjavur-613007, Tamil Nadu, India
}

${ }^{3}$ Department of Chemistry, Kunthavai Naacchyiaar Government Arts College for Women (Affiliated to Bharathidasan University), Thanjavur613007, Tamil Nadu, India

\section{Article Info:}

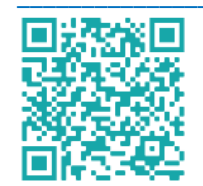

\section{Article History:}

Received 18 August 2021 Reviewed 30 September 2021 Accepted 08 October 2021 Published 15 October 2021

\section{Cite this article as:}

Jain N, Chandra Mohan S, Sumathi S, Mechanisms of Action of Flavonoids in the Management of Diabetes mellitus, Journal of Drug Delivery and Therapeutics. 2021; 11(5-S):194-202

DOI: http://dx.doi.org/10.22270/jddt.v11i5-S.5101

*Address for Correspondence:

S. Chandra Mohan,

${ }^{1}$ Department of Chemistry, Sarvepalli Radhakrishnan University, NH-12, Hoshangabad Road, Jatkhedi, Bhopal- 462026, Madhya Pradesh, India.

2 Division of Phytochemistry, Shanmuga Centre for Medicinal Plants Research, Thanjavur-613007, Tamil Nadu, India

\section{Abstract}

Management of diabetes mellitus is a challenge for clinicians. Uncontrolled hyperglycemia increases the risk of microvascular and macrovascular complications, damaging the body systems. Although a number of antidiabetic drugs are available for therapeutic intervention, toxicity, loss of efficacy in chronic use and high cost of treatment have necessitated the search for new molecules to manage diabetes. Safety and cost are the main prerequisite for the new antidiabetic molecules. Medicinal plants and their purified phytochemicals have shown promising antidiabetic potential in the past few years. The flavonoids can be widely classified into different categories like anthocyanins, catechins, flavanols, flavones, flavanones etc. Some flavonoids have hypoglycemic properties. They may improve al-tered glucose and oxidative metabolisms of diabetic states. The hypoglycemic effect of some herbal extracts has been confirmed in human and animal models of type 2 diabetes mellitus (T2DM). Some of the important phytoconstituents from the classes of flavonoid have been discussed here. The current review summarizes the antidiabetic activity of flavonoids, the mechanism-based action of flavonoids that target the various metabolic pathways in humans.

Keywords: Diabetes mellitus, Flavonoids, Medicinal plants, mechanisms of action, T2DM

*Corresponding author: cm_123ss@yahoo.co.in

\section{INTRODUCTION}

DM is a metabolic disorder characterized by chronic hyperglycemia together with disturbances in the metabolism of carbohydrates, proteins and fat, which in general results from an insulin availability and need imbalance ${ }^{1-4}$. DM can be manifested as type 1 (T1DM), or type 2 (T2DM) 5,6. T2DM is the most common presentation of DM, resulting from both cell dysfunction (with altered insulin levels) and impaired insulin action (insulin resistance) ${ }^{6-8}$. Management of Diabetes mellitus employs modifications of diet, change of lifestyle, intake of oral hypoglycemic, administration of exogenous insulin and herbal remedies ${ }^{9}$. Synthetic drugs are fraught with adverse side effects ${ }^{10,11}$. Natural products such as plants and herbs have the capacity to reduce blood glucose values and ameliorate diabetes with reduced adverse side effects. They achieve this owing to the presence of phytochemicals such as flavonoids, saponins, alkaloids, tannins, glycosides, terpenes etc. The aim of this review is to highlight the importance of flavonoids in the management of D. mellitus. The mechanisms by which these active ISSN: 2250-1177 principles of flavonoids origin bring about their effects are also discussed.

\section{FLAVONOIDS}

Flavonoids are a group of plant metabolites that constitute a family of soluble polyphenolic compounds. They are made up of two benzene rings attached by a short three carbon chain ${ }^{12}$. Flavonoids that occur in nature are classified into six classes namely: anthocyanidins (e.g. cyanidin, delphinidin, malvidin, peonidin, petunidin etc), flavan-3-ols (e.g. catechin, epicatechin, gallocatechin etc), flavonols (isorhamnetin, kaempferol, myricetin, quercetin), flavones (e.g. apigenin, luteolin, baicalein, chrysin), flavanones (eriodictyol, hesperetin, naringenin) and isoflavones (daidzein, genistein, glycitein, biochanin A) ${ }^{12,13}$. The antidiabetic properties of flavonoids are attributed partly to their antioxidant potentials and partly due to their ability to modulate some cell signalling. Dietary flavonoids occur in fruits, vegetables, beverages, chocolates, herbs and 
plants ${ }^{14,15}$. The following flavonoids isolated from plants have been shown to possess anti-diabetic properties.

\section{(a) Diosmin}

Diosmin is a flavonoid that occurs in citrus plants naturally. Experimental evidencs have revealed its potent anti-diabetic activities mediated by decreases in the level of glycosylated haemoglobin, increases in the activities of glutathione peroxidases 16,17 , significant reductions in plasma glucose values, increases in hepatic hexokinases and glucose-6phosphate dehydrogenases ${ }^{18}$, increasing insulin levels and ameliorating oxidative stress as evidenced by assay of superoxide dismutase, catalase and glutathione peroxidase activities. It also increased the levels of vitamins $C$ and $\mathrm{E}^{19}$ Diosmin is isolated from Scrophularia nodosa, an antidiabetic plant.

\section{(b) Fisetin}

This flavonoid brings about its anti-diabetic effect by inhibiting gluconeogenesis through inhibition of mitochondrial pyruvate transport and a decrease in the cytosolic NADH/NAD redox ${ }^{20}$. Decreasing of glycogen breakdown, plasma glucose levels, glycosylated haemoglobin, mRNA and protein expression levels of gluconeogenic genes like phosphoenol pyruvate carboxykinase and by increasing plasma insulin are among the mechanisms by which fisetin brings about its antidiabetic actions ${ }^{21}$. Moreover, hypoglycaemic activities of fisetin flavonoids have been associated with significant decreases in nuclear factor kappa B (NF-kB) p65 unit, interleukin-1 $\beta$ (IL-1 $\beta$ )and serum nitric oxide (NO)21. Fisetin, produced by Cotinus coggygriaScop and also found ubiquitously in strawberry, apple, grape, onions and cucumber has been advocated for use in the prevention of diabetes 22,23 .

\section{(c) Morin}

Morin-treated diabetic rats showed anti-diabetic activities by improvement of antioxidant agents, reduction of insulin resistance, decrease in oxidative stress parameters, normalization of lipids and lipoproteins and decreases in the levels of tumour necrosis factor alpha (TNF $\alpha) 24$. Experimental evidence also suggests that morin reduced inflammatory cytokines IL- $1 \beta$ and IL- 6 in diabetic animals ${ }^{25}$. Recovery of hepatic insulin and leptin sensitivity, reduction in hyperlipidaemia and liver-lipid accumulation have been fingered as mechanisms by which morin brings about its anti-diabetic actions ${ }^{26}$. Morin has been shown to reduce glucose-6-phosphatase activities, increase hexokinase, and glucose-6-phosphate dehydrogenase activities and insulin levels ${ }^{27}$. Morin is contained in many medicinal herbs such as Prunus dulcis(Mill), Chlorophora tinctoria(L), Psidium guajava ${ }^{28,29}$.

\section{(d) Eriodictyol}

Suppression of oxidative stress, up-regulation of mRNA expression of peroxisome proliferator-activated receptor gamma (PPAR $\gamma$ ) and adipocyte-specific fatty acid-binding protein together with the protein levels of PPAR $\gamma 2$ in differentiated 3T3-L1 adipocytes are key mechanisms involved in the anti-diabetic activity of eriodictyol. It has also been implicated in the reduction of retinal $\mathrm{TNF} \alpha$, intercellular adhesion molecule-1 (ICAM-1), vascular endothelial growth factor (VEGF), endothelia nitric oxide synthase (eNOS) and lipid peroxides ${ }^{30,31}$. Lemon fruits contain eriodictyol in abundance ${ }^{32}$.

\section{(e) Hesperidin}

This flavonoid is ubiquitous in plants of the genus citrus especially Citrus aurantium ${ }^{33,34}$. Like eridictyol, hesperidin exhibits anti-diabetic activity by down regulating the generation of free radicals and the release of proinflammatory cytokines ${ }^{35-37}$. Normalization of the lipids and adiponectin together with alterations of the activities of glucose metabolizing enzymes decreases in the levels of thiobarbituric acid reactive substances (TBARS) and increases in the activities of lactate dehydrogenase (LDH) have been reported with hesperidin administration ${ }^{38,39}$.

\section{(f) Naringenin}

Citrus fruits and tomatoes contain naringenin in abundance, which confers antioxidant properties to these fruits ${ }^{40}$. Cochlospermun also contains naringenin in large amount ${ }^{41}$. Naringenin inhibits $\alpha$ glucosidase activities. It also inhibits glucose uptake in vitroand interferes with genes associated with lipid metabolism ${ }^{42,43}$. Activation of $5^{\prime}$ AMP-activated protein kinase (AMPK), enhancement of antioxidant activities, reduction of insulin resistance and improvement in hepatic function markers are also thought to be the mechanism of action of naringenin ${ }^{44-46}$.

\section{(g) Apigenin}

This flavone flavonoid is ubiquitous in citrus, onions, vegetables, tea and nut ${ }^{47}$. Its mechanism of action is through the improvement of antioxidant parameters, enhancement of glucose transporter 4 (GLUT4) translocation and beta cell preservation 48,49 .

\section{(h) Baicalein}

Baicalein scavenges free radicals, induces insulin production, reduces glycosylated haemoglobin, suppresses the activation of NF-kB, decreases the expression of inducible nitric oxide synthase (iNOS) and transforming growth factor beta (TGF- $\beta)^{50,51}$. Another major mechanism by which Baicalein operates is by up-regulation of AMPK44. This flavonoid is present in the roots of Scutellaria baicalensisand fruits of Oroxylum indicum ${ }^{52,53}$.

\section{(i) Chrysin}

It is a major component of Oroxylum indicum. It has also been isolated from Passiflora caerulea, Pelargonium peltatum, Tilia tomentosa, bee pollen, honey, fruits and vegetables ${ }^{54-56}$. Treatment with chrysin has been associated with suppression of TGF- $\beta$, fibronectin, and collagen-IV protein expression in the kidney. Serum levels of IL-1 $\beta$ and IL-6 were also reduced. With these observations, chrysin is thought to prevent nephropathy ${ }^{51}$. Chrysin administration also improves insulin levels and reduces lipid peroxidation $^{57}$.

\section{(j) Luteolin}

Luteolin is known to potentiate insulin action and increase transcriptional activation of PPAR $\gamma^{58}$. Luteolin also decreases circulating levels of inflammatory molecules, Monocyte Chemotactic Protein-1 (MCP-1), resistin and elevates adiponectin levels in obese mice ${ }^{59}$. It is also on record that luteolin improves insulin secretion60. Luteolin is found in abundance in carrots, peppers, cabbage, apple, vegetables and fruits ${ }^{61-63}$.

\section{(k) Tangeretin}

Tangeretin administration decreased total cholesterol, leptin, resistin, IL6 and MCP-164. It is also in the literature that its administration significantly decreased glycosylated haemoglobin, improved insulin levels, enhanced glycolytic enzymes, controlled glucose metabolism in hepatic tissues 
and decreased an insulin-resistant factor, MCP-1 in 3T3-L1 adipocytes ${ }^{65}$. Rinds of citrus fruits contain tangeretin.

\section{(l) Wogonin}

This is obtained from the root of Scutellaria baicalensis ${ }^{66}$. Wogonin interferes with insulin sensitivity and lipid metabolism through its effect on AMPK and PPAR $\alpha^{67}$.

\section{(m) Isorhamnetin}

It is an anti-diabetic principle isolated from Hippophae rhamnoides, Oenanthe javanica and Ginkgo biloba. Its administration reduces oxidative stress, inhibits sorbitol accumulation and interferes with lipid metabolism ${ }^{68-70}$.

\section{(n) Kaempferol}

This flavonol is present in Ginkgo biloba, tea, grapefruits, edible berry and vegetables ${ }^{71-73}$. Its administration is associated with the inhibition of apoptosis, reduction of caspase-3 activity in beta cells, improvement of cAMP signalling and enhancement of insulin synthesis and secretion $^{74}$. It is also associated with the enhancement of antioxidant production and reduction of IL-1 $\beta, \mathrm{TNF} \alpha$, lipid peroxidation, nitrite and glycosylated haemoglobin ${ }^{75,76}$.

\section{(o) Rutin}

Oranges, grapes, buckwheat, lemons, limes, berries and peaches contain rutin 77,78 . Proposed mechanisms for the antihyperglycemic effect of rutin include a decrease of carbohydrates absorption from the small intestine, inhibition of tissue gluconeogenesis, an increase of tissue glucose uptake, stimulation of insulin secretion from beta cells, and protecting Langerhans islet against degeneration. Rutin also decreases the formation of sorbitol, reactive oxygen species, advanced glycation endproduct precursors, and inflammatory cytokines. These effects are considered to be responsible for the protective effect of rutin against hyperglycemia- and dyslipidemiainduced nephropathy, neuropathy, liver damage, and cardiovascular disorders. ${ }^{79,80}$.

\section{(p) Quercetin}

It is a flavonol flavonoid present in onions, berries, apples, pepper and coriander81,82. Its anti-diabetic actions are exhibited by increases in anti-oxidant enzymes, decreases in lipid peroxidation, reduction in intestinal glucose absorption by inhibiting GLUT283,84. Quercetin blocks tyrosine kinase and also the recovery of cell proliferation85.

\section{(q) Genistein}

This is an isoflavone flavonoid present in legumes. Sophora subprostrala and Genista tinctoria contain genistein ${ }^{86}$. Renal
TBARS were reduced upon genistein administration. It also improves glucose tolerance and increases blood insulin level without affecting body weight ${ }^{87}$.

\section{(r) Daidzein}

Daidzein, an isoflavone flavonoid is present in nuts, soybeans and fruits. Daidzein improves lipid and glucose metabolism, improves insulin sensitivity and enhances AMPK phosphorylation in muscles ${ }^{88-91}$.

\section{(s) Cyanidin}

Cyanidin, an anthocyanin flavonoid exhibits its anti-diabetic actions by inhibiting $\alpha$-glucosidase and pancreatic $\alpha$ amylase ${ }^{92}$. It also prevents pancreatic apoptosis and improves antioxidant status ${ }^{93,94}$.

\section{(t) Delphinidin}

This is anthocyanin present in berries, tomatoes, egg plant, vegetables, carrots, sweet potatoes, red cabbage and red onions. Its anti-diabetic activity is mediated through its antioxidant effects and reductions in albumin and haemoglobin glycations ${ }^{95}$.

\section{(u) Pelargonidin}

It is present in blackberries, cranberries, ripe raspberries and blueberries ${ }^{96}$. Its administration relieves oxidative stress, nitrite levels and stimulates insulin secretion. In diabetic rats, pelargonidin showed it reduces the formation of thiobarbituric acid reactive substances (TBARS) and antioxidant defensive enzymes levels ${ }^{97,98}$. Structure of some flavonoids shown in Figure 1.

\section{PLANT DERIVED FLAVONOIDS AND THEIR METABOLIC PATHWAYS}

Plants contain numerous chemical compounds having medicinal values and include alkaloids, amino acids, amines and carboxylic acid derivatives, anthranoids, carbohydrates, glycosides, flavanoids, minerals, vitamins and inorganic compounds, peptidoglycans, polyphenol and its derivatives, saponins, and so on. These compounds are extracted from different parts of the various plants. This review aims to document and summarize the present knowledge about the mechanism-based action of antidiabetic plants, with emphasis on their flavonoids that target the various metabolic pathways in humans. The review has been organized according to various flavonoids, targeted metabolic pathways and plant sources in Table 1. 
<smiles>COc1ccc(-c2cc(=O)c3c(O)cc(OC4OC(CO[C@@H]5OC(C)[C@H](O)[C@H](O)[C@H]5O)[C@@H](O)[C@H](O)[C@H]4O)cc3o2)cc1O</smiles><smiles>O=C1C(O)=CC=C2OC1=Cc1ccc(O)cc1O2</smiles>

(b) Fisetin<smiles></smiles>

(c) Morin<smiles>COc1cc(O)cc2c1C(=O)C[C@@H](c1ccc(O)c(O)c1)O2</smiles>

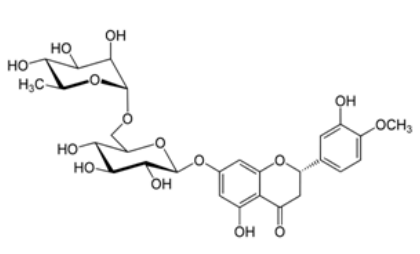

(e) Hesperidin<smiles>O=c1cc(-c2ccccc2)oc2cc(O)c(O)c(O)c12</smiles>

(h) Baicalein<smiles>O=C1C[C@H](c2ccc(O)cc2)Oc2cc(O)cc(O)c21</smiles><smiles>O=c1cc(-c2ccccc2)oc2cc(O)cc(O)c12</smiles><smiles>O=c1cc(-c2ccc(O)c(O)c2)oc2cc(O)cc(O)c12</smiles>

(j) Luteolin<smiles>COc1ccc(-c2cc(=O)c3c(OC)c(OC)c(OC)c(OC)c3o2)cc1</smiles>

(k) Tangeretin<smiles>COc1c(O)cc(O)c2c(=O)cc(-c3ccccc3)oc12</smiles><smiles>COc1cc(-c2oc3cc(O)cc(O)c3c(=O)c2O)ccc1O</smiles>

(m) Isorhamnetin<smiles>O=c1c(O)c(-c2ccc(O)cc2)oc2cc(O)cc(O)c12</smiles>

(n) Kaemp ferol<smiles>O=c1c(-c2ccc(O)cc2)coc2cc(O)cc(O)c12</smiles>

(q) Genistein<smiles>COc1ccc(-c2coc3cc(O)ccc3c2=O)cc1</smiles>

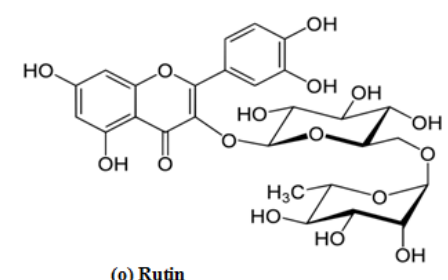

(o) Rutin<smiles></smiles><smiles>O=c1oc2cc(O)cc(O)c2cc1-c1cc(O)c(O)c(O)c1</smiles>

(t) Delphinidin<smiles>Oc1ccc(-c2[o+]c3cc(O)cc(O)c3cc2O)cc1</smiles>

(u) Pelargonidin

Figure 1: Structure of some flavonoids 
Table 1: Various flavonoids having hypoglycaemic potential that regulate intermediates of diatmetabolic pathways.

\begin{tabular}{|c|c|c|c|c|}
\hline S. N. & Flavonoids & $\begin{array}{l}\text { Targeted metabolic } \\
\text { pathways }\end{array}$ & Plant Source & Ref \\
\hline 1 & Chrysin, isoquercitrin & Insulin secretion & Morus alba & [99] \\
\hline 2 & $\begin{array}{l}\text { Epigallocatechin-gallate, gallocatechin, } \\
\text { epicatechin, }(+) \text { catechin, }(-) \text { epicatechin }\end{array}$ & $\begin{array}{l}\text { Free radical scavenging } \\
\text { activity, } \\
\text { insulinonematinactivity }\end{array}$ & $\begin{array}{l}\text { Camellia sinensis, Punica granatum, } \\
\text { Satureja khuzestanica,Bauhinia forficate }\end{array}$ & $\begin{array}{l}{[100-} \\
102]\end{array}$ \\
\hline 3 & $\begin{array}{l}\text { Myrciaphenones A and B,myrciacitrins } \\
\text { I and II }\end{array}$ & Insulin secretion & Myrcia multiflora & {$[103]$} \\
\hline 4 & $\begin{array}{l}\alpha \text {-Cephalin, myricetin-3'-glucoside, } \\
\text { ambrettolide }\end{array}$ & Insulin secretion & Abelmoschus moschatus & {$[103]$} \\
\hline 5 & $\begin{array}{l}\text { Cytrus bioflavonoids (hesperidin, } \\
\text { naringin) }\end{array}$ & $\begin{array}{l}\text { Glycogen synthesis,glycolysis, } \\
\text { gluconeogenesis }\end{array}$ & Camellia sinensis & {$[104]$} \\
\hline 6 & Flavanols, flavones,flavanones & Insulin secretion & Panax notoginseng & [105] \\
\hline 7 & $\begin{array}{l}\text { Quercetin, quercetrin, apigenin, rutin, } \\
\text { apigenin-7- O-glucoside }\end{array}$ & Insulin secretion & $\begin{array}{l}\text { Urtica dioica, Bauhinia varigtla, Ginkgo } \\
\text { biloba }\end{array}$ & {$[106]$} \\
\hline 8 & Naringenin & Insulin secretion & Camellia sinensis & {$[101]$} \\
\hline 9 & Soy isoflavones (genistein, diadzein) & $\begin{array}{l}\text { Lipid and glucose metabolism, } \\
\text { PPARactivation }\end{array}$ & Glycin max, Curcuma longa & $\begin{array}{l}{[107,} \\
108]\end{array}$ \\
\hline 10 & Proanthocyanidins & Insulinonematic activity & Vitis vinifera & [109] \\
\hline 11 & $\alpha$-Terpineol, hexanol & Insulin secretion & Agaricus campestris & [110] \\
\hline 12 & Kaempferitrin & Glycolysis & Bauhinia candicans, Bauhinia forficate & [111] \\
\hline 13 & $\begin{array}{l}(+) \text { Catechin, (-)epicatechin, chiorogenic } \\
\text { acid, liquiritigenin, isoliquiritigerin }\end{array}$ & Insulinomematic activity & $\begin{array}{l}\text { Phylanthus embelica, Acacia Arabica, } \\
\text { Pterocarpus marsupium, Phylanthus } \\
\text { embelica }\end{array}$ & [112] \\
\hline 14 & $\begin{array}{l}\text { Silymarin, silybin, silychristin, } \\
\text { silidianin }\end{array}$ & HMG Co A suppression & Silybum marianum & {$[$ [113] } \\
\hline 15 & Kaempferol, isorhamnetin & $\begin{array}{l}\text { Free radical scavenging } \\
\text { activity }\end{array}$ & Ginkgo biloba & {$[106]$} \\
\hline 16 & $\begin{array}{l}\text { Tribulusamides A and B, kaempferol- } \\
\text { 3- } \beta \text {-D-(6'P- coumaroyl)glucoside, } \\
\text { kaempferol-3-glucoside }\end{array}$ & $\begin{array}{l}\text { Insulin secretion, free radical } \\
\text { scavenging activity }\end{array}$ & Tribulus terrestris & $\begin{array}{l}{[114,} \\
115]\end{array}$ \\
\hline 17 & Leucopelargonidin, dulcitol & Insulin secretion & Casearia esculenta & {$[116]$} \\
\hline 18 & $\begin{array}{l}\text { Matteuorien, matteuorienin } \\
\text { matteuorienate A, B, C }\end{array}$ & Insulin secretion & Matteuccia orientalis & [117] \\
\hline
\end{tabular}

Research into D. mellitus and its management in recent times has been geared towards isolation of efficacious active antidiabetic agents of natural origin. A lot of studies have been carried out in various medicinal plants in this regard. Results have not only indicated that many medicinal plants possess anti-diabetic potentials but have demonstrated specific bioactive anti-diabetic principles and various mechanisms of actions of these agents. Bioactive anti-diabetic principles of plant origin are mainly phytochemicals, these phytochemicals act in a number of diverse mechanisms to bring about their anti-diabetic effects. Some of the mechanisms involved include increase in insulin secretion, decreases in hepatic glucose output, regulation of certain enzymes involved in carbohydrate metabolism such as $\alpha$ glucosidase inhibitors, modulation of certain regulation molecules such as PPAR $\gamma$, hypolipidaemic activities, antioxidant effects, interference with the activities of some glycolytic enzymes such as phosphoenolpyruvate carboxykinase activities, amelioration of glycosylated haemoglobin, enhancement of the expression of glucose transporters and others.

Flavonoids were observed to be the most popular antidiabetic principle among the phytochemicals. These naturally occurring secondary plant metabolites
(Phytochemicals) hold great potential for production of marketable, novel and effective anti-diabetic drugs in near future. In general, bioactive anti-diabetic agents of plant origin constitute a group of natural products that have recently gained popularity in the health sector for management of various ailments such as diabetes mellitus. Satisfactory management of D. mellitus in future is pivotal on medicinal plants.

\section{CHALLENGES USING FLAVONOIDS}

Flavonoids have been proven to be strong candidates to reduce the pathogenesis of diabetes and its complications. The modulatory anti-diabetic effects of flavonoids reduce apoptosis and insulin resistance and enhance insulin secretion and GLUT 4 translocation ${ }^{118}$. Efforts have been made to establish an optimal human dietary consumption level of flavonoids worldwide, the consumption level of flavonoids depend on dietary habits, geographical location, socioeconomic status, food processing and preparation method, solubility of flavonoids, and the ethnicity of the population. To date, no recommended dosage of flavonoids has been reported due to the heterogeneity of their molecular structure and the limited information about their bioavailability. Major advances in understanding flavonoids 
bioavailability have been made, but the challenge to overcome problems, such as cellular permeability, solubility, excretion, and metabolic alternation, are still lacking. Research groups are trying to enhance flavonoids bioavailability by targeting absorption sites, improving metabolic stability and intestinal absorption ${ }^{119}$.

\section{CONCLUSION}

Diabetes is possibly the world's fastest growing meta-bolic disease, and as knowledge of the heterogeneity of this disorder increases, so does the need for more appropriate therapies. Traditional plant medicines are used throughout the world for the management of diabetes because it is easily and cheaply available. The scientific validation of several plant species has proved the efficacy of the botanicals in management of diabetes acting through various mechanisms. There is a tapping need to search and develop new herbal formulations and nutraceuticals from natural resources especially with pure phytochemicals for the treatment of diabetes and to avoid serious diabetic complications. A systematic research and development in the form of drug delivery systems are necessary to explicate the pharmacological activities of herbal remedies being used nowadays to treat diabetes mellitus. The study of such medicines might offer a natural key to unlock a diabetologist's pharmacy for the future.

Conflict of Interest: The authors confirm that this article content has no conflict of interest.

\section{REFERENCES}

1. Porth CM, Essentials of Pathophysiology: Concepts of Altered Health States, 3rd ed.; Wolters Kluwer: Alphenaan den Rijn, The Netherlands, 15 October 2010; Volume 3. ISBN-10 1582557241; ISBN-13 978-1582557243

2. Nogueira C, Souto SB, Vinha E, Braga DC, Carvalho D, Oral glucose lowering drugs in type 2 diabetic patients with chronic kidney disease, Hormones (Athens) 2013; 12:483-494. https://doi.org/10.14310/horm.2002.1436

3. Souto, SB, Souto EB, Braga DC, Medina JL, Prevention and current onset delay approaches of type 2 diabetes mellitus (T2DM), Eur J Clin Pharmacol, 2011; 67:653-661. https://doi.org/10.1007/s00228-011-1038-z

4. Vieira R, Souto SB, Sanchez-Lopez E, Machado AL, Severino P, Jose S, et. al., Sugar-Lowering Drugs for Type 2 Diabetes Mellitus and Metabolic Syndrome-Strategies for In Vivo Administration: PartII, J Clin Med, 2019; 8:1332. https://doi.org/10.3390/jcm8091332

5. Ali MA, Wahed MI, Khatune NA, Rahman BM, Barman RK, Islam MR, Antidiabetic and antioxidant activities of ethanolic extract of Semecarpus anacardium (Linn.) bark, BMC Complement Altern Med, 2015; 15:138. https://doi.org/10.1186/s12906-015-0662$\mathrm{Z}$

6. Bebernitz GR, Dain JG, Deems RO, Otero DA, Simpson WR Strohschein RJ, Reduction in Glucose Levels in STZ Diabetic Rats by 4-(2,2-Dimethyl-1-oxopropyl)benzoic acid AProdrugApproach for Targeting the Liver, J Med Chem, 2001; 44:512-523. https://doi.org/10.1021/jm000264w

7. Scheen AJ, Pharmacodynamics,Ecacy and Safety of SodiumGlucose Co-Transporter Type 2 (SGLT2) Inhibitors for the Treatment of Type 2 Diabetes Mellitus, Drugs, 2015; 75:33-59. https://doi.org/10.1007/s40265-014-0337-y

8. Vivot K, Pasquier A, Goginashvili A, Ricci R, Breaking Bad and Breaking Good: Beta-Cell Autophagy Pathways in Diabetes, J Mol Biol, 2019. https://doi.org/10.1016/j.jmb.2019.07.030

9. Venkatesh S, Madhava Reddy B, Dayanand Reddy G, Mullangi R and Lakshman M, Antihyperglycemic and hypolipidemic effects of Helicteres isoraroots in alloxan-induced diabetic rats: A possible mechanism of action, J Nat Med, 2010; 64:295-304. https://doi.org/10.1007/s11418-010-0406-9

10. Pareek H, Sharma S, Khajja B S, Jain K and Jain G C, Evaluation of hypoglycemic and anti hyperglycemic potential of Tridax procumbens(Linn.), BMC Compl Altern Med, 2009; 9:48 https://doi.org/10.1186/1472-6882-9-48

11. Meenakshi P, Bhuvaneshwari R, Rathi M A, Thirumoorthi L Guravaiah D C, Jiji M, et al., Antidiabetic activity of ethanolic extract of Zaleya decandrain alloxan-induced diabetic rat, Appl Biochem Biotechnol, 2010; https://doi.org/10.1007/s12010-009-8871-x

12. Manach C, Scalbert A, Morand C, Remesy C and Jimenez L, Polyphenols: Food sources and bioavailability, Am J Clin Nutr, 2013; 79:727-747. https://doi.org/10.1093/ajcn/79.5.727

13. Xiao J, Kai G, Yamamoto $\mathrm{K}$ and Chen $\mathrm{X}$, Advance in dietary polyphenols as alpha glucosidases inhibitors: A review on structure-activity relationship aspect, Crit Rev Food Sci Nutr, 2013; $53: 818-836$ https://doi.org/10.1080/10408398.2011.561379

14. Robertson S, What are flavonoids, New Med Life Sci Med, 2016, https://www.news-medical.net/health/what- are-Flavonoidsaspx.

15. Ramachandran $V$ and Baojun $X$, Antidiabetic properties of dietary flavonoids: A cellular mechanism review, Nutr Metabol, 2015; 12:60. https://doi.org/10.1186/s12986-015-0057-7

16 Manuel Y, Keenoy B, Vertommen J and De Leeuw I, The effect of flavonoid treatment on the glycation and antioxidant status in type I diabetic patients, Diabetes Nutr Metabol, 1999; 12:256-63.

17. Campanero MA, Escolar M, Perez G, Garcia-Quetglas E, Sadaba B et al., Simultaneous determination of diosmin and diosmetin in human plasma by ion trap liquid chromatography-atmospheric pressure chemical ionization tandem mass spectrometry: Application to a clinical pharmacokinetic study, J Pharm Biomed Anal, 2010; 51:875-81. https://doi.org/10.1016/j.jpba.2009.09.012

18. Pari L and Srinivasan S, Antihyperglycemic effect of diosmin on hepatic key enzymes of carbohydrate metabolism in streptozotocin-nicotinamide-induced diabetic rats, Biomed Pharmacother, 2010; 64:477-81. https://doi.org/10.1016/j.biopha.2010.02.001

19. Srinivasan $S$ and Pari L. Antihyperlipidemic effect of diosmin: A citrus flavonoid on lipid metabolism in experimental diabetic $\begin{array}{llll}\text { rats, J Funct Foods, 2010; 5:484-92. } & \text {; }\end{array}$ https://doi.org/10.1016/j.jff.2012.12.004

20. Constantin RP, Constantin J, Pagadigorria CL, Ishii-Iwamoto EL, Bracht A, et al., The actions of fisetin on glucose metabolism in the rat liver, Cell Biochem Funct, 2010; 28:149-58 https://doi.org/10.1002/cbf.1635

21. Prasath GS, Pillai S and Subramanian SP, Fisetin improves glucose homeostasis through the inhibition of gluconeogenic enzymes in hepatic tissues of streptozotocin induced diabetic rats, European J Pharmacol, 2014; 740:248-54 https://doi.org/10.1016/j.ejphar.2014.06.065

22. Arai Y, Watanabe S, Kimira M, Shimoi K, Mochizuki R, et al., Dietary intakes of flavonols, flavones and isoflavones by Japanese women and the inverse correlation between quercetin intake and plasma LDL cholesterol concentration, J Nutr, 2000; 130:2243-2250. https://doi.org/10.1093/jn/130.9.2243

23. Kim MS, Hur HJ, Kwon DYand Hwang JT, Tangeretin stimulates glucose uptake via regulation of AMPK signaling pathways in C2C12 myotubes and improves glucose tolerance in high-fat diet-induced obese mice, Mol Cell Endocrinol, 2012; 358:127134. https://doi.org/10.1016/j.mce.2012.03.013

24. Sendrayaperumal V, Iyyam Pillai S and Subramanian S, Design, synthesis and characterization of zinc-morin, a metal flavonol complex and evaluation of its anti-diabetic potential in HFD-STZ induced type 2 diabetes in rats, Chem-Biol Interact, 2014; 219:917. https://doi.org/10.1016/j.cbi.2014.05.003 
25. Abuohashish HM, Al-Rejaie SS, Al-Hosaini KA, Parmar MY and Ahmed MM, Alleviating effects of morin against experimentallyinduced diabetic osteopenia, Diabetol Metab Syndr, 2013; 5:5. https://doi.org/10.1186/1758-5996-5-5

26. Wang X, Zhang DM, Gu TT, Ding XQ, Fan CY, et al.,Morin reduces hepatic inflammation-associated lipid accumulation in high fructose-fed rats via inhibiting sphingosine kinase 1/sphingosine 1-phosphate signaling pathway, Biochem Pharmacol, 2013; 86:1791-804. https://doi.org/10.1016/j.bcp.2013.10.005

27. Vanitha $\mathrm{P}$, Uma C, Suganya N, Bhakkiyalakshmi E Suriyanarayanan S, et al., Modulatory effects of morin on hyperglycemia by attenuating the hepatic key enzymes of arbohydrate metabolism and $\beta$-cell function in streptozotocininduced diabetic rats, Environ Toxicol Pharmacol, 2014; 37:32635. https://doi.org/10.1016/j.etap.2013.11.017

28. Sreedharan V, Venkatachalam KK and Namasivayam N, Effect of morin on tissue lipid peroxidation and antioxidant status in 1, 2dimethylhydrazine induced experimental colon carcinogenesis, Invest New Drugs, 2009; 27:21-30. https://doi.org/10.1007/s10637-008-9136-1

29. Ricardo KFS, Toledo de Oliveira T, Nagem TJ, Pinto AS, Oliveira MGA, et al.,Effect of flavonoids morin; quercetin and nicotinic acid on lipid metabolism of rats experimentally fed with triton, Brazillian Arch Biol Technol, 2001; 44:263-267. https://doi.org/10.1590/S1516-89132001000300007

30. Zhang WY, Lee JJ, Kim Y, Kim IS, Han JH, et al., Effect of eriodictyol on glucose uptake and insulin resistance in vitro , J Agric Food Chem, 2012; 60:7652-7658. https://doi.org/10.1021/jf300601z

31 Bucolo C, Leggio GM, Drago F and Salomone S, Eriodictyol prevents early retinal and plasma abnormalities in streptozotocin-induced diabetic rats, Biochem Pharmacol, 2012; 84: 88-92. https://doi.org/10.1016/j.bcp.2012.03.019

32. Miyake $\mathrm{Y}$, Yamamoto $\mathrm{K}$, Tsujihara N and Osawa T, Protective effects of lemon flavonoids on oxidative stress in diabetic rats, Lipids, 1998; 33:689-695. https://doi.org/10.1007/s11745998-0258-y

33. Emim JA, Oliveira AB and Lapa AJ, Pharmacological evaluation of the anti-inflammatory activity of a citrus bioflavonoid, hesperidin, and the isoflavonoids, duartin and claussequinone, in rats and mice, J Pharm Pharmacol,1994; 46:118-122. https://doi.org/10.1111/j.2042-7158.1994.tb03753.x

34. Kawaguchi K, Mizuno T, Aida K and Uchino K, Hesperidin as an inhibitor of lipases from porcine pancreas and Pseudomonas, Biosci Biotechnol Biochem,1997; 61:102-104. https://doi.org/10.1271/bbb.61.102

35. Visnagri A, Kandhare AD, Chakravarty S, Ghosh P and Bodhankar SL, Hesperidin, a flavanoglycone attenuates experimental diabetic neuropathy via modulation of cellular and biochemical marker to improve nerve functions, Pharm Biol, 2014; 52:814828. https://doi.org/10.3109/13880209.2013.870584

36. Gumieniczek A, Effect of the new thiazolidinedione-pioglitazone on the development of oxidative stress in liver and kidney of diabetic rabbits, Life Sci, 2003; 74:553-562. https://doi.org/10.1016/j.lfs.2003.03.004

37. Shi X, Liao S, Mi H, Guo C, Qi D, et al., Hesperidin prevents retinal and plasma abnormalities in streptozotocin-induced diabetic rats, $\quad$ Molecules, 2012; 17:12868-12881. https://doi.org/10.3390/molecules171112868

38. Akiyama S, Katsumata S, Suzuki K, Ishimi Y, Wu J, et al.,Dietary hesperidin exerts hypoglycemic and hypolipidemic effects in streptozotocin-induced marginal type 1 diabetic rats, J Clin Biochem Nutr, 2010; 46:87-92. https://doi.org/10.3164/jcbn.09-82

39. Yo A, Sharma P K, Shrivastava B, Ojha S, Upadhya HM, et al.,Hesperidin produces cardioprotective activity via PPAR- $\gamma$ pathway in ischemic heart disease model in diabetic rats, PLoS One, 2014; 9:111-212. https://doi.org/10.1371/journal.pone.0111212
40. Wilcox LJ, Borradaile NM and Huff MW, Anti-atherogenic properties of naringenin, a citrus flavonoid, Cardiovasc Drug Rev,1999; 17:160-178. https://doi.org/10.1111/j.15273466.1999.tb00011.x

41. Sanchez-Salgado JC, Ortiz-Andrade RR, Aguirre-Crespo F, Vergara-Galicia J, Leon-Rivera I, et al, Hypoglycemic, vasorelaxant and hepatoprotective effects of Cochlospermum vitifolium(willd.) sprengel: A potential agent for the treatment of metabolic syndrome, J Ethnopharmacol, 2007; 109:400-405. https://doi.org/10.1016/j.jep.2006.08.008

42. Priscilla DH, Roy D, Suresh A, Kumar V and Thirumurugan K Naringenin inhibits $\alpha$-glucosidase activity: A promising strategy for the regulation of postprandial hyperglycemia in high fat diet fed streptozotocin induced diabetic rats, Chem-Biol Interac, 2014; 210:77-85. https://doi.org/10.1016/j.cbi.2013.12.014

43. Li JM, Che CT, Lau CBS, Leung PS and Cheng CHK, Inhibition of intestinal andrenal $\mathrm{Na}+$-glucose co-transporter by naringenin, Int J Biochem Cell Biol, 2006; 38:985-995. https://doi.org/10.1016/j.biocel.2005.10.002

44. Pu P, Gao DM, Mohamed S, Chen J, Zhang J, et al.,Naringin ameliorates metabolic syndrome by activating AMP-activated protein kinase in mice fed a high-fat diet, Arch Biochem Biophys, 2012; 518:61-70. https://doi.org/10.1016/j.abb.2011.11.026

45. Zygmunt K, Faubert B, MacNeil J and Tsiani E, Naringenin, a citrus flavonoid, increases muscle cell glucose uptake via AMPK, Biochem Biophys Res Commun, 2010; 398:178-183. https://doi.org/10.1016/j.bbrc.2010.06.048

46. Priscilla DH, Jayakumar $\mathrm{M}$ and Thirumurugan $\mathrm{K}$, Flavanone naringenin: An effective antihyperglycemic and antihyperlipidemic nutraceutical agent on high fat diet fed streptozotocin induced type 2 diabetic rats, J Funct Foods, 2015; 14:363-373. https://doi.org/10.1016/j.jff.2015.02.005

47. Ross JA and Kasum CM, Dietary flavonoids: Bioavailability, metabolic effects, and safety, Annual Rev Nutr, 2002; 22:19-34 https://doi.org/10.1146/annurev.nutr.22.111401.144957

48. Hossain CM, Ghosh MK, Satapathy BS, Dey NS and Mukherjee B, Apigenin causes biochemical modulation, GLUT4 and Cd38 alterations to improve diabetes and to protect damages of some vital organs in experimental diabetes, Am J Pharmacol Toxicol, 9; 39-52. https://doi.org/10.3844/ajptsp.2014.39.52

49. Panda S and Kar A, Apigenin, 4',5,7-trihydroxyflavone regulates hyperglycaemia, thyroid dysfunction and lipid peroxidation in alloxan-induced diabetic mice, J Pharm Pharmacol, 2007; 59:1543-1548. https://doi.org/10.1211/jpp.59.11.0012

50. Stavniichuk R, Drel VR, Shevalye H, Maksimchyk Y, Kuchmerovska TM, et al.,Baicalein alleviates diabetic peripheral neuropathy through inhibition of oxidative-nitrosative stress and p38 MAPK activation, Exp Neurol, 2011; 230:106-113. https://doi.org/10.1016/j.expneurol.2011.04.002

51. Ahad A, Mujeeb M, Ahsan $\mathrm{H}$ and Siddiqui WA, Prophylactic effect of baicalein against renal dysfunction in type 2 diabetic rats, Biochem, 2014; 106:101-110. https://doi.org/10.1016/j.biochi.2014.08.006

52. Kim YO, Leem K, Park J, Lee P, Ahn DK, et al., Cytoprotective effect ofScutellaria baicalensis in CA1 hippocampal neurons of rats after global cerebral ischemia, J Ethnopharmacol, 2001; 77:183-88. https://doi.org/10.1016/S0378-8741(01)00283-5

53. Lapchak PA, Maher P, Schubert D and Zivin J A, Baicalein, an antioxidant12/15-lipoxygenase inhibitor improves clinical rating scores following multiple infarct embolic strokes, Neurosci, 2007; 150:585-591. https://doi.org/10.1016/j.neuroscience.2007.09.033

54. Siess MH, LeBon AM, Canivenc-Laver MC, Amiot MJ, Sabatier S, et al.,Flavonoids of honey and propolis: Characterization and effects on hepatic drug-metabolising enzymes and benz[a]pyr ene-DNA binding in rats, J Agric Food Chem,1996; 44:23792383. https://doi.org/10.1021/jf9504733 
55. Dhawan K, Kumar S and Sharma A, Beneficial effects of chrysin and benzoflavone on virility in 2-year-old male rats, J Med Food, 2002; 5:43-48. https://doi.org/10.1089/109662002753723214

56. Sandborn WJ and Faubion WA, Clinical pharmacology of inflammatory bowel disease therapies, Curr Gastroenterol Rep, 2000; 2:440-445. https://doi.org/10.1007/s11894-000-0005-0

57. Sirovina D, Orsolić N, Koncić MZ, Kovacević G, Benković V, et al, Quercetin vs chrysin: Effect on liver histopathology in diabetic mice, Human Exp Toxicol, 2013; 32:1058-1066. https://doi.org/10.1177/0960327112472993

58. Ding L, Jin D and Chen X, Luteolin enhances insulin sensitivity via activation of PPAR $\gamma$ transcriptional activity in adipocytes, J Nutr Biochem, 2010;

21:941-947. https://doi.org/10.1016/j.jnutbio.2009.07.009

59. Liu Y, Fu X, Lan N, Li S, Zhang J, et al.,Luteolin protects against high fat diet-induced cognitive deficits in obesity mice, Behav Brain Res, 2014 267:178-188. https://doi.org/10.1016/j.bbr.2014.02.040

60. Ding Y, Shi X, Shuai X, Xu Y, Liu Y, et al.,Luteolin prevents uric acid-induced pancreatic $\beta$-cell dysfunction, J Biomed Res, 2014; 28:292-298.

61. Neuhouser ML, Dietary flavonoids and cancer risk: Evidence from human population studies, Nutr Cancer, 2004; 50:1-7. https://doi.org/10.1207/s15327914nc5001_1

62. Miean $\mathrm{KH}$ and Mohamed S, Flavonoid (myricetin, quercetin, kaempferol, luteolin, and apigenin) content of edible tropica plants, J Agric Food Chem, 2001; 49:3106-3112. https://doi.org/10.1021/jf000892m

63. Gates MA, Tworoger SS, Hecht JL, De Vivo I, Rosner B, et al.,A prospective study of dietary flavonoid intake and incidence of epithelial ovarian cancer, Int J Cancer, 2007; 12: 2225-2232. https://doi.org/10.1002/ijc.22790

64. Kim MS, Hur HJ, Kwon DY and Hwang JT, Tangeretin stimulates glucose uptake via regulation of AMPK signaling pathways in C2C12 myotubes and improves glucose tolerance in high-fat diet-induced obese mice, Mol Cell Endocrinol, 2012; 358:127134. https://doi.org/10.1016/j.mce.2012.03.013

65. Ku SK and Bae JS, Baicalin, baicalein and wogonin inhibits high glucose-induced vascular inflammation in vitroand in vivo, BMB Rep, 2015 ; https://doi.org/10.5483/BMBRep.2015.48.9.017

66. Tai MC, Tsang SY, Chang LY and Xue H, Therapeutic potential of wogonin: A naturally occurring flavonoid, CNS Drug Rev, 2005; 11:141-150. 3458.2005.tb00266.x

67. Bak EJ, Kim J, Choi YH, Kim JH, Lee DE, et al.,Wogonin ameliorates hyperglycemia and dyslipidemia via PPAR $\alpha$ activation in $\mathrm{db} / \mathrm{db}$ mice, Clin Nutr, 2014; 33:156-163. https://doi.org/10.1016/j.clnu.2013.03.013

68. Yokozawa T, Kim HY, Cho EJ, Choi JS and Chung HY, Antioxidant effects of isorhamnetin 3,7-di-O-beta-D-glucopyranoside isolated from mustard leaf (Brassica juncea) in rats with streptozotocin-induced diabetes, J Agric Food Chem, 2002; 50:5490-495. https://doi.org/10.1021/jf0202133

69. Lee YS, Lee S, Lee HS, Kim BK, Ohuchi K, et al., Inhibitory effects of isorhamnetin-3-0-beta-D-glucoside fromSalicornia herbacea on rat lens aldose reductase and sorbitol accumulation in streptozotocin-induced diabetic rat tissues, Biol Pharm Bullet, 2005; 28:916-918. https://doi.org/10.1248/bpb.28.916

70. Rodríguez-Rodríguez C, Torres N, Gutiérrez-Uribe JA, Noriega LG, Torre-Villalvazo I, et al.,The effect of isorhamnetin glycosides extracted from Opuntia ficus indica in a mouse model of diet induced obesity, Food Funct, 2015; 6:805-815. https://doi.org/10.1039/C4F001092B

71. An G, Gallegos J and Morris ME, The bioflavonoid kaempferol is an abcg2 substrate and inhibits abcg2-mediated quercetin efflux, Drug Metab Dispos, 2011; 39:426-432. https://doi.org/10.1124/dmd.110.035212
72. Hakkinen SH, Karenlampi SO, Heinonen IM, Mykkanen HM and Torronen AR, Content of the flavonols quercetin, myricetin, and kaempferolin 25 edible berries, J Agric Food Chem, 1999; 47:2274-2279. https://doi.org/10.1021/jf9811065

73. Nirmala $\mathrm{P}$ and Ramanathan M, Effect of kaempferol on lipid peroxidation and antioxidant status in 1,2-dimethyl hydrazine induced colorectal carcinoma in rats, Eur J Pharm, 2011; 654:7579. https://doi.org/10.1016/j.ejphar.2010.11.034

74. Zhang $\mathrm{Y}$ and Liu D, Flavonol kaempferol improves chronic hyperglycemia-impaired pancreatic beta-cell viability and insulin secretory function, Eur J Pharmacol, 2011; 670:325-332. https://doi.org/10.1016/j.ejphar.2011.08.011

75. Al-Numair KS, Chandramohan G, Veeramani C and Alsaif MA Ameliorative effect of kaempferol, a flavonoid, on oxidative stress in streptozotocin-induced diabetic rats, Redox Rep, 2015; 20:198-209.

https://doi.org/10.1179/1351000214Y.0000000117

76. Abo-Salem OM, Kaempferol attenuates the development of diabetic neuropathic pain in mice: Possible anti-inflammatory and anti-oxidant mechanisms, Maced J Med Sci, 2014; 7:424430. https://doi.org/10.3889/oamjms.2014.073

77. Kreft S, Knapp M and Kreft I, Extraction of rutin from buckwheat (Fagopyrum esculentumMoench) seeds and determination by capillary electrophoresis, J Agric Food Chem,1999; 47:46494652. https://doi.org/10.1021/jf990186p

78. Huang WY, Zhang HC, Liu WX and Li CY, Survey of antioxidant capacity and phenolic composition of blueberry, blackberry and strawberry in Nanjing, J Zhe Univ Sci B, 2012; 13:94-102. https://doi.org/10.1631/jzus.B1100137

79. Ghorbani A, Mechanisms of antidiabetic effects of flavonoid rutin, Biomedicine \& Pharmacotherapy, 2017; 96:305-312. https://doi.org/10.1016/j.biopha.2017.10.001

80. Niture NT, Ansari AA and Naik SR, Anti-hyperglycemic activity of rutin in streptozotocin-induced diabetic rats: an effect mediated through cytokines, antioxidants and lipid biomarkers, Indian J Exp Biol, 2014; 52:720-727.

81. Hollman PCH, de Vries JHM, van Leeuwen SD, Mengelers MJB and Katan MB, Absorption of dietary quercetin glycosides and quercetin in healthy ileostomy volunteers, Am J Clin Nutr, 1995; 62:1276-1282. https://doi.org/10.1093/ajcn/62.6.1276

82. Alinezhad H, Azimi A, Zare M, Ebrahimzadeh MA, Eslami S, et al.,Antioxidant and antihemolytic activities of ethanolic extract of flowers, leaves, and stems ofHyssopus officinalis L. var. angustifolius, Int J Food Prop, 2013; 16:1169-1178. https://doi.org/10.1080/10942912.2011.578319

83. Coskun O, Kanter M, Korkmaz A and Oter S, Quercetin, a flavonoid antioxidant, prevents and protects streptozotocininduced oxidative stress and beta-cell damage in rat pancreas, Pharmacol Res, 2005; 51:117-123. https://doi.org/10.1016/j.phrs.2004.06.002

84. Stewart LK, Wang Z, Ribnicky D, Soileau J L, Cefalu WT, et al.,Failure of dietary quercetin to alter the temporal progression of insulin resistance among tissues of $\mathrm{C} 57 \mathrm{BL} / 6 \mathrm{~J}$ mice during the development of diet-induced obesity, Diabetologia, 2009, 52:514-523. https://doi.org/10.1007/s00125-008-1252-0

85. Kobori M, Masumoto S, Akimoto $\mathrm{Y}$ and Takahashi Y, Dietary quercetin alleviates diabetic symptoms and reduces streptozotocin-induced disturbance of hepatic gene expression in mice, Mol Nutr Food Res, 2009; 53:859-868. https://doi.org/10.1002/mnfr.200800310

86. Patisaul HB and Jefferson $W$, The pros and cons of phytoestrogens, Front Neuroendocrinol, 2010; 31:400-419. https://doi.org/10.1016/j.yfrne.2010.03.003

87. Elmarakby AA, Ibrahim AS, Faulkner J, Mozaffari MS, Liou GI, et al.,Tyrosine kinase inhibitor, genistein, reduces renal inflammation and injury in streptozotocin induced diabetic mice, Vascul Pharmacol, 2011; 55:149-156. https://doi.org/10.1016/j.vph.2011.07.007 
88. Kapiotis S, Jilma B and Szalay Y, Evidence against an effect of endothelin-1 on blood coagulation, fibrinolysis, and endothelial cell integrity in healthy men, Arterioscler Thromb Vasc Biol, 1997;

https://doi.org/10.1161/01.ATV.17.11.2861

$17: 2861-2867$

89. Park SA, Choi MS, Cho SY, Seo JS, Jung UJ, et al., Genistein and daidzein modulate hepatic glucose and lipid regulating enzyme activities in C57BL/Ks J-db/db mice, Life Sci, 2006; 79:12071213. https://doi.org/10.1016/j.lfs.2006.03.022

90. Cederroth CR, Vinciguerra M, Gjinovci A, Kuhne F, Klein M, et al., Dietary phytoestrogens activate AMP-activated protein kinase with improvement in lipid and glucose metabolism, Diabetes, 2008; 57:1176-1185. https://doi.org/10.2337/db07-0630

91. Cheong SH, Furuhashi K, Ito K, Nagaoka M, Yonezawa T, et al., Daidzein promotes glucose uptake through glucose transporter 4 translocation to plasma membrane in L6 myocytes and improves glucose homeostasis in type II diabetic model mice, J Nutr Biochem, 2014; 25:136-143. https://doi.org/10.1016/j.jnutbio.2013.09.012

92. Akkarachiyasit S, Charoenlertkul $P$, Yibchok-Anun $S$ and Adisakwattana $S$, Inhibitory activities of cyanidin and its glycosides and synergistic effect with acarbose against intestinal $\alpha$-glucosidase and pancreatic $\alpha$-amylase, Int J Mol Sci, 2010; 11:3387-3396. https://doi.org/10.3390/ijms11093387

93. Nasri S, Roghani M, Baluchnejadmojarad $\mathrm{T}$, Rabani $\mathrm{T}$ and Balvardi M, Vascular mechanisms of cyanidin-3-glucoside response in streptozotocin-diabetic rats, Pathophysiol, 2011 18:273-278. https://doi.org/10.1016/j.pathophys.2011.03.001

94. Zhu W, Jia Q, Wang Y, Zhang Y and Xia M, The anthocyanin cyanidin-3-0-betaglucoside, a flavonoid, increases hepatic glutathione synthesis and protects hepatocytes against reactive oxygen species during hyperglycemia: Involvement of a cAMPPKA-dependent signaling pathway, Free Rad Biol Med, 2012 52:314-327.

https://doi.org/10.1016/j.freeradbiomed.2011.10.483

95. Gharib A, Faezizadeh Z and Godarzee M, Treatment of diabetes in the mouse model by delphinidin and cyanidin hydrochloride in free and liposomal forms, Planta Medica, 2013; 79:1599-1604 https://doi.org/10.1055/s-0033-1350908

96. Mazza G, Compositional and functional properties of saskatoon berry and blueberry, Int J Fruit Sci , 2005; 5:101. https://doi.org/10.1300/J492v05n03_10

97. Mirshekar, M.; Roghani, M.; Khalili, M.; Baluchnejadmojarad, T. Chronic oral pelargonidin alleviates learning and memory disturbances in streptozotocin diabetic rats. Iran J Pharm Res, 2011; 10:569-575.

98. Mirshekar M, Roghani M, Khalili M, Baluchnejadmojarad T and Arab M S, Chronic oral pelargonidin alleviates streptozotocininduced diabetic neuropathic hyperalgesia in rat: Involvement of oxidative stres, Iranian Biomed J, 2010; 14:33-39.

99. Roman-Ramos R, Flores-Saenz JL and Alarcon-Aguilar FL, Antihyperglycemic effect of some edible plants, J Ethnopharmacol, 1995; 48: 25-32. https://doi.org/10.1016/03788741(95)01279-M

100. Hii SCT and Howell SL, Effects of epicatechin on rat islets of Langerhans, Diabetes 1984; 33: 291-296. https://doi.org/10.2337/diabetes.33.3.291

101. Waltner-Law ME, Wang XL, Law BK, Epigallocatechin gallate: a constituent of green tea, represses hepatic glucose production, J Biol Chem, 2002; 277: 34933-34940. https://doi.org/10.1074/jbc.M204672200

102. Vessal M, Hemmati $M$ and Vasei M, Hypoglycemic effects of quercetin in streptozocin-induced diabetic rats: comparative biochemistry and physiology, Toxicol Pharmacol, 2003; 135:357-364. https://doi.org/10.1016/S1532-0456(03)001406
103. Ngueyem TA, Brusotti G, Caccialanza G, The genus Bridelia: a phytochemical and ethnopharmacological review, J

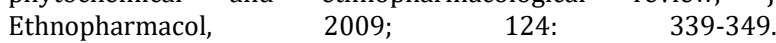
https://doi.org/10.1016/j.jep.2009.05.019

104. Jung UJ, Lee MK, Jeong KS, The hypoglycemic effects of hesperidin and naringin are partly mediated by hepatic glucoseregulating enzymes in $\mathrm{C} 57 \mathrm{BL} / \mathrm{Ks} \mathrm{J}-\mathrm{db} / \mathrm{db}$ mice, J Nutr, 2004; 134:2499-2503. https://doi.org/10.1093/jn/134.10.2499

105. Liu KZ, Li JB, Lu HL, Effects of Asiragalus and saponins of Panax notoginseng on MMP-9 in patients with type 2 diabetic, Macroangiopathy, 2004; 29:264-266.

106. Jellin JM, Batz F and Hitchens $\mathrm{K}$, Pharmacist's letter/prescriber's letter natural medicines comprehensive database. Stockton, CA: Therapeutic Research Faculty, 1999.

107. Howes JB, Tran D, Brillante D, Effects of dietary supplementation with isoflavones from red clover on ambulatory blood pressure and endothelial function in postmenopausal type 2 diabetes. Diabetes Obes Metab, 2003; 5:325-332. https://doi.org/10.1046/j.1463-1326.2003.00282.x

108. Mezei O, Banz WJ, Steger RW, Soy isoflavones exert hypoglycemic and hypolipidemic effects through the PPAR pathways in obese Zucker rats and murine RAW 264.7 cells, J

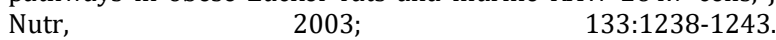
https://doi.org/10.1093/jn/133.5.1238

109. Gray AM and Flatt PR, Insulin-releasing and insulin-like activity of Agaricus campestris (mushroom), J Endocrinol, 1998; 157:259-266. https://doi.org/10.1677/joe.0.1570259

110. Pinent M, Blay M, Blade MC, Grape seed-derived procyanidins have an antihyperglycemic effect in streptozotocin-induced diabetic rats and insulinomimetic activity in insulin-sensitive cell lines, Endocrinology, 2004; 145:4985-4990. https://doi.org/10.1210/en.2004-0764

111. Jorge AP, Horst $H$, de Sousa E, et al, Insulinomimetic effects of kaempferitrin on glycaemia and on glucose uptake in rat soleus muscle, Chem Biol Interact, 2004; 149: 89-96. https://doi.org/10.1016/j.cbi.2004.07.001

112. Van de Venter M, Roux S, Bungu LC, Antidiabetic screening and scoring of 11 plants traditionally used in South Africa, J Ethnopharmacol, 2008; 119: 81-86. https://doi.org/10.1016/j.jep.2008.05.031

113. Huseini HF, Larijani B, Heshmat R, The efficacy of Silybum marianum(L.) Gaertn (Silymarin) in the treatment of type 2 diabetes: a randomized, double-blind, placebo-controlled clinical trial. Phytother Res, 2006; 20:1036-1039. https://doi.org/10.1002/ptr.1988

114. Cooper EJ, Hudson AL, Parker CA, Effects of the beta-carbolines, harmane and pinoline, on insulin secretion from isolated human islets of Langerhans, Eur J Pharmacol, 2003; 482:189-196. https://doi.org/10.1016/j.ejphar.2003.09.039

115. Kirtikar KR and Basu BD, Indian medicinal plants, vol 1, 1998.

116. Prakasam A, Sethupathy S and Pugalendia KV. Antiperoxidative and antioxidant effects of Casearia esculentaroot extract in streptozotocin induced diabetic rats, Yale J Biol Med, 2005; 78:15-23.

117. Shane-McWhorter L, Biological complementary therapies: a focus on botanical products in diabetes, Diabetes Spectr, 2001; 14:199-208. https://doi.org/10.2337/diaspect.14.4.199

118. Abotaleb M, Samuel SM, Varghese E, Varghese S, Kubatka P, Liskova A, Busselberg D, Flavonoids in Cancer and Apoptosis. $\begin{array}{lll}\text { Cancers } & \text { (Basel), 2018; } & \text { 11:28. }\end{array}$ https://doi.org/10.3390/cancers11010028

119. AL-Ishaq RK, Abotaleb M, Kubatka P, Kajo K, Büsselberg D, Flavonoids and Their Anti-Diabetic Effects: Cellular Mechanisms and Effects to Improve Blood Sugar Levels, Biomolecules. 2019; 9:430. 